\title{
Why did Challenger matter?
}

\section{The loss last week of the US shuttle Challenger has in some sense shocked the world. It would be good if it helped the United States to a better programme.}

THE: anguish in the United States and around the world about last week's shuttle accident requires explanation. Why was this accident so much more compelling of public grief than, say, the loss of more than 200 US servicemen in an aircraft accident in Newfoundland just before Christmas or the other even more horrific accidents that studded 1985? There are two threads in any account of how last week's tragedy gripped the sombre imagination of the whole world, of which the first is the proof that Challenger provided that Marshall McLuhan's "global village" is now indeed a reality. The television cameras that recorded both the destruction of the spacecraft and the personal grief of the relatives of its occupants made personal tragedies general. The same television cameras brought the Vietnam war into the living rooms of the United States just over a decade ago, with awesome consequences. Last year, there was the famine in Ethiopia. Nobody will or should complain at the discovery, now, that the global village will increasingly haunt us.

The second reason for the sense of national tragedy in the United States last week is that Challenger carried with it into the Atlantic some of the sense of hope that the United States has cherished for its space programme. The competition in technology from Japan may have turned from an irritation to a cause for dismay, international problems that once seemed small, as in Central America, the Middle East and Central Europe, have turned out to be devilishly complicated, but there seemed, until last week, a high chance that the United States would win a new set of spurs for having made space travel by people into a routine happening. That there might nevertheless be an accident was always on the cards; reason says that the only question to answer was not "whether" but "when". But it is natural, and understandable, that people's pride should have given way to profound disappointment. Mourning is an appropriate mechanism of catharsis. That there has been, with the State of the Union message postponed a week, and the government's tight timetable with it. So what will happen now?

\section{Future}

President Reagan says the shuttle programme will continue, and his decision has been echoed, mostly with enthusiasm, throughout the United States. That, no doubt, is what the seven brave men and women who died with Challenger would have wished. Any other decision would turn the present sense of disappointment into one of outright failure. And, for strictly practical reasons, there is no choice. The Pentagon has been anxious about the reliability of the shuttle, and its turn-round time, for years, and is refurbishing some Titan rockets as satellite launchers until a batch of ten specialized rockets are delivered in 1988 or so; but, for some time, the three surviving models of the shuttle have a crucial job to do. The queue of commercial satellites waiting to be put in orbit is also long, and lengthening; and delay means more than mere cost. But this year was also intended to be a good year for launching scientific satellites, of which the Hubble Space Telescope (originially due to go up in August) is by far the most important. The scientific community, of which an influential part is fond of saying that the objectives of the space programme could all more surely and safely be attained with unmanned rockets, should remember that this important instrument will require repeated visits by a shuttle crew during the fifteen years of its intended life.

So what lessons are to be learned? The hardest is that there are no simple lessons. No doubt the National Aeronautics and Space Adminstration will soon find the cause of last week's accident, modify the remaining spacecraft accordingly and restart the programme. In its short time at work, the shuttle has in any case amply demonstrated its usefulness, if not its effectiveness in economic terms. But one of the lasting casualties of last week's accident will be the administration's ambition to put the operation of the shuttle on a commercial footing. Another will be the notion that the entire ambition of the United States in space can be sustained by one chief launching instrument. It would be safer and probably also cheaper to keep the shuttle for the jobs that only the shuttle can carry out, using some other rocket to put everyday satellites into orbits. The obvious difficulty, in the year when the Gramm-Rudman Act will be playing havoc with the federal budget, is that there is no obvious place from which the extra funds can come. But it will be a great misfortune if last week's mood of resolution is too quickly lost in squabbling about budgets.

\section{Plans}

That is why it is sensible that the White House is taking a wider look at the future of the space programme as a whole. There are too many anomalies for comfort built into plans for the immediate future. Even Spacelab is an embarrassment, with its complicated arrangements for anticipating what the future could hold by running electrophoresis experiments whose time has not yet come. But the United States is more ambitiously committed to the concept of building a space station somewhere up there. Would it not make sense to let that plan lapse? Certainly the lobby that has been building up to send some kind of mission to Mars had better go into hiding for a while. None of this implies that the successes of the past few years now count for nothing; it is merely that they have enjoyed a run of luck, statistical in nature, that could not have been anticipated. To succeed with the help of luck is no shame, of course, but to expect that the luck will never run out is unwise.

There was particular sadness last week about the death of Christa McAuliffe, the New Hampshire schoolteacher on the shuttle. She had responded to President Reagan's offer, during the 1984 election campaign, to send a schoolteacher into space as an inspiration to students and, perhaps, also to the National Education Association, which seemed to be on the point of endorsing Mr Walter Mondale, Mr Reagan's chief opponent for the presidency. The unpalatable truth is that the venture was a publicity stunt of a kind too often foisted on the US space programme in the past, sometimes by its own managers. What last week's tragedy shows is that there is now no case for carrying on shuttle flights passengers whose presence is not essential. There should be no more schoolteachers, congressmen or even journalists (see Nature 319, 250; 1986) until experience has shown shuttle flights to be mere routine. On the sad showing of last week, that will take some time. 